ISBN 978-81-943403-5-5

18th ROME - ITALY International Conference on Art History, Literature, Social Sciences and

Education (AHLSE-20)

Rome (Italy) Feb. 3-5, 2020

\title{
Portuguese Literature and the Classics: from the Aesthetic Values to the Eternal Message of Pure Infinity
}

\author{
L. Cardoso ${ }^{1}$ \\ ${ }^{1}$ Department of Languages and Communication, Polytechnic Institute of Portalegre (Portugal)
}

\begin{abstract}
The Classic European Mouvement influenced Europe from the end of the Middle Ages and later on during the Neo-Classicism. These periods represent a set of key aesthetic guidelines, bringing together a common matrix with the identity of Latin and Greek Culture. The essence of this movement is the basis for a European Union, leaving behind the Middle Ages and creating the dawn for Humanism and the rebirth of Equilibrium and Perfection
\end{abstract}

Keywords: Portuguese Literature, Classicism, Latin and Greek Culture

\section{Introduction}

We can find the classic movement in Europe in two different periods: after the Middle Ages and before the Romantic period. Nevertheless, the two moments share the same basis: the Latin and Greek Culture that supported a new concept of Man and of Art. The Classics offer a set of characteristics in aesthetics, a background for a common theoretical framework, a common ideology of creation, a new meaning for the role of the artist and a new horizon of faith in mankind's ability for building a new society with strong values and the perfection of the aesthetic creation. The Encyclopædia Britannica defines this period as follows:

Classicism and Neoclassicism, in the arts, historical tradition or aesthetic attitudes based on the art of Greece and Rome in antiquity. In the context of the tradition, Classicism refers either to the art produced in antiquity or to later art inspired by that of antiquity; Neoclassicism always refers to the art produced later but inspired by antiquity. Thus the terms Classicism and Neoclassicism are often used interchangeably. (...) When used to refer to an aesthetic attitude, Classicism invokes those characteristics normally associated with the art of antiquity - harmony, clarity, restraint, universality, and idealism. Because of the high regard accorded to ancient art, "classic" is sometimes used to mean that the example is the best of its type (e.g., a classical example of a villa). By extension, "classic" is also sometimes used to refer to a stage of development that some historians and aestheticians have identified as a regular feature of what they have seen as the cyclical development of all styles. In such schemes the Classical phase is the moment at which the style is at its fullest and most harmonious expression; this phase is generally thought to follow a primitive or less completely realized phase and to precede a "mannered," "baroque," or "decadent" phase in which the style loses its original forcefulness and is sometimes meaninglessly elaborated. Phases of Western art history that intentionally imitate the antique example directly are usually called Neoclassical. (...) Periods of Classicism in literature and music have generally coincided with the Classical periods in the visual arts. In literature, for instance, the first major revival of Classicism also occurred during the Renaissance, 
when Cicero's prose was especially imitated. France in the 17th century developed a rich and diversified Classicism in literature, as it had also in the visual arts. The dramatists Pierre Corneille and Jean Racine, together with the philosophers Blaise Pascal and René Descartes, were particularly important. In England, Classicism in literature arose later than in France and reached its zenith in the 18th-century writings of John Dryden and Alexander Pope. Gotthold Ephraim Lessing, Johann Wolfgang von Goethe, and Friedrich Schiller were major figures in the German Classical literary movement. In the early 20th century, T.S. Eliot and proponents of the New Criticism were sometimes considered classicists because of their emphasis on form and discipline. (...) (2020)

The Longman Active Dictionary defines "classics" as follows:

The following of ancient Greek or Roman principles and style in art and literature, generally associated with harmony, restraint, and adherence to recognized standards of form and craftsmanship, especially from the Renaissance to the 18th century. Often contrasted with romanticism. The following of traditional and long-established theories or styles. The revival of a classical style or treatment in art, literature, architecture, or music. (2004, p. 114)

One of the authors who best describes the periods of Classicism and Neo-Classicism in Portugal is Aguiar e Silva who defines Classicism and Neo-Classicism in Portugal, identifying, in the first place, a common basis:

Classicism, conceptualized as a system of literary norms and standards historically situated and determined, results from a long process of maturation of aesthetic-literary ideas, developed over three centuries and encompassing several countries. (...) Classicism has its roots in the Italian Renaissance, receiving from it some of its fundamental elements: the notions of artistic model and imitation of Greek and Latin authors, the principles of the timelessness of beauty and the need for rules, the taste for perfection, for the stability, clarity and simplicity of artistic structures. In the formation of his doctrine, the wide movement of critical exegesis verified in Italy, in the second half of the 16th century, around Aristotle's Poetics played a very important role. (2006, p. 507 - 508)

Aguiar e Silva identifies the following characteristics that are present in Portuguese Literature and European Literature: the poetics of classicism, verisimilitude, imitation of nature, intellectualism, rules, imitation of GreekLatin models, conveniences, purpose moral of literature (2006, p. 515 - 529). Parkinson et alii (2012) also highlight these domains and drawing on cultural anthropology and Social Identity Theory, Wiater (2011) explores the world-view bound up with classicist criticism. Only from within this ideological framework can we understand why Greek and Roman intellectuals in Augustan Rome strove to speak and write like Demosthenes, Lysias, and Isocrates.

As Abbamonte and Harrison wrote:

Research into the return of the knowledge of Greek to Western Europe has suffered for a long time from the lack of intersection of skills and fields of research: to fully understand this phenomenon, one has to go back a very long way through the tradition of the texts and their reception in contexts as different as the Middle Ages and the beginning of Renaissance humanism. However, over the past thirty years, scholars have demonstrated the crucial role played by the return of knowledge of Greek in the transformation of European culture, both through the translation of texts and through the direct study of the language. In addition, the actual translations from Greek into Latin remain poorly studied and a clear understanding of the intellectual and cultural contexts that produced them is lacking. In the Middle Ages, the knowledge of Greek was limited to isolated areas that had no reciprocal links. As had happened to many Latin authors, all Greek literature was rather neglected, perhaps because a number of philosophical texts had already been available in translation from the seventh century AD, or 
because of a sense of mistrust, due to their ethnic and religious differences. Between the 12th and 14th century $\mathrm{AD}$, a change is perceptible: the sharp decrease in Greek texts and knowledge in the South of Italy, once a reference point for this kind of study, was perhaps an important reason prompting Italian humanists to go and study Greek in Constantinople.

Over the past thirty years, it has become evident to scholars that humanism, through the reappreciation of classical antiquity, created a bridge to the modern era, which also includes the Middle Ages. The criticism by the humanists of medieval authors did not prevent them from using a number of tools that the Middle Ages had developed or synthesized: glossaries, epitomes, dictionaries, encyclopaedias, translations, commentaries. At present one thing that is missing, however, is a systematic study of the tools used for the study of Greek between the 15th and 16th century; this is truly important, because, in the following centuries, Greek culture provided the basis of European thought in all the most important fields of knowledge. (2019)

That is why Portuguese Literature adopted these domains e characteristics in close connection with the Italian Rennaissance, the Italian Humanism and the European classic movement in general. Defying time and space, classics could now offer a way to eternity, by creating a work of art capable of resisting changes and temporality and always maintaining the puré and perfect call of eternity.

\section{References}

[1] Abbamonte, G. (Ed.) \& Harrison, S. (Ed.) (2019). Making and Rethinking the Renaissance. Between Greek and Latin in 15th-16th Century Europe. Berlin, Boston: De Gruyter. Retrieved 26 Jan. 2020, from https://www.degruyter.com/view/product/533179

https://doi.org/10.1515/9783110660968

[2] Parkinson, S. et alii (2012) A Companion to Portuguese Literature., Journal of Iberian and Latin American Research, 18:2, 185-187, DOI: 10.1080/13260219.2012.740829

[3] Silva, V. (1986) Teoria da Literatura. Coimbra: Almedina

[4] The Editors of Encyclopaedia Britannica (2020) Romanticism In Encyclopædia Britannica. London: Encyclopædia Britannica, inc. https://www.britannica.com/art/Neoclassicism (access 20.01.2020)

[5] Wellek, R. (1963) Concepts of Criticism. Yale: Yale University Press

[6] Wehmeir, S. (2004) Longman Active Study Dictionary. Ed. Della Summers. Harlow: Pearson

[7] Wiater, N. (2011). The Ideology of Classicism. Language, History, and Identity in Dionysius of Halicarnassus. Berlin, Boston: De Gruyter. Retrieved 26 Jan. 2020, from https://www.degruyter.com/view/product/129472 https://doi.org/10.1515/9783110259117



L. Cardoso was born in Viseu (Portugal) in 1969. After concluding the Humanities degree at the Catholic University in 1991, he concluded a Master in Classic Literatures at Coimbra University, in 1996. In 2007 he concluded his PhD in Modern Languages and Works of literature at Coimbra University (Portugal). After teaching for four years in secondary schools, he began teaching at the Polytechnic Institute of Viseu in 1995 until 2008, when he moved to the Polytechnic Institute of Portalegre as Adjunct Professor. He was elected Dean of the School of Education and Social Sciences in 2010 until february 2018, completing the two mandates permitted by law. Since 2015 until May, 2018, he was also President of ARIPESE - the Association for Reflexion and Intervention in Higher Schools Polytics. Main interests in teaching and investigation include Science and Communication Languages, Literature and Cinema, and Management of Higher Education Universities. In 2016, he published Literature and Cinema: the look of Janus. Vergílio Ferreira and the space of the unspeakable. Prof. Dr. Cardoso was the national coordinator for the Bologna Process in Polytechnics in Media and Communication Sciences. He is a member of several international organizations concerning Education, Communication, Comparative Literature, Narratology, Film Studies and Higher Education Management and reviewer of several international journals. He has published several papers in national and international journals with peer review and is a member of C3i - Polytechnic Institute of Portalegre and of the Center for Comparative Studies of the University of Lisbon. 